\title{
Hydrochemistry and geothermometry of thermal water in northeastern Morocco
}

\author{
Abdelhakim Jilali ${ }^{*} \mathbb{B}$, Abdelkarim Chamrar ${ }^{2}$ and Abdelilah El Haddar ${ }^{2}$
}

\author{
${ }^{*}$ Correspondence: \\ yamaapa@hotmail.com \\ ${ }^{1}$ Ministry of Energy, \\ Mines, and Sustainable \\ Development, Abou \\ Marouane Essaadi Street, \\ Rabat-Institut, BP 6208, Haut \\ Agdal, Rabat, Morocco \\ Full list of author information \\ is available at the end of the \\ article
}

\begin{abstract}
Thermal water in northeastern Morocco is a promising, sustainable resource of energy. To date, thermal water has not been used as a source of renewable energy in Morocco as no clear strategy has yet been developed for its use. In this study, 10 samples (boreholes and springs) of thermal water distributed within the basin of the Moulouya River were assessed, and their physical and chemical parameters (such as temperature, $\mathrm{pH}$, electrical conductivity (EC), and major ionic composition, including the $\mathrm{K}^{+}, \mathrm{Na}^{+}, \mathrm{Ca}^{2+}$, $\mathrm{Mg}^{2+}, \mathrm{Cl}^{-}, \mathrm{SO}_{4}{ }^{2-}, \mathrm{NO}_{3}{ }^{-}, \mathrm{NO}_{2}{ }^{-}, \mathrm{NH}_{4}{ }^{+}, \mathrm{H}_{2} \mathrm{PO}_{4}{ }^{-}, \mathrm{CO}_{3}{ }^{2-}$, and $\mathrm{HCO}_{3}{ }^{-}$) were measured. The results show that the temperature, $\mathrm{pH}$, and $\mathrm{EC}$ range between 28 and $55^{\circ} \mathrm{C}$ (as measured in field), 5.46 and 7.50, and 478 and $15,580 \mu \mathrm{S} / \mathrm{cm}$, respectively. Furthermore, the results indicate the presence of four main hydrogeochemical facies dominating the hydrogeological system, which are $\mathrm{Na}-\mathrm{Cl}, \mathrm{Na}-\mathrm{Ca}-\mathrm{Cl}, \mathrm{Ca}-\mathrm{Mg}-\mathrm{HCO}_{3}$, and $\mathrm{Na}-\mathrm{Ca}-\mathrm{HCO}_{3}$. The geothermal reservoirs of the different samples were investigated by the means of several geochemical methods, including the Giggenbach Na-K-Mg diagram, two geothermometers $(\mathrm{Na}-\mathrm{K}-\mathrm{Mg})$, and the determination of the saturation index. We noticed different estimated geothermal reservoir temperatures over the range $80-170{ }^{\circ} \mathrm{C}$.
\end{abstract}

Keywords: Thermal water, Hydrochemistry, Geothermometers, Northeast Morocco

\section{Background}

During the last three decades, many geothermal studies have been conducted in different parts of Morocco (Rimi and Lucazeau 1987; Rimi et al. 1998; Zarhloule et al. 1998, 2001, 2005; Tassi et al. 2006; Zarhloule et al. 2007; Rimi et al. 2012). Recently, some work has been carried out in the northeast part of Morocco to study the geothermal water potential (Barkaoui et al. 2014; Jilali et al. 2015b). For this purpose, different geothermometers were used to estimate the geothermal temperature, such as Giggenbach diagrams, alkaline and silica geothermometers, and the saturation index (Ahmad et al. 2002; Asta et al. 2012; Pürschel et al. 2013; Makni et al. 2014; Trabelsi et al. 2015; Wang et al. 2015). The same techniques were previously used in different parts of Morocco (Cidu and Bahaj 2000; Zarhloule et al. 2005; Tassi et al. 2006; Barkaoui et al. 2014).

One of the goals of this study has been to add a new thermal waters point in the Moulouya Basin in the northeastern part of Morocco, and for this 10 samples were subjected to detailed physico-chemical analyses. This work provides detailed information about the estimated temperatures in the geothermal reservoir using different geothermometers. 


\section{Study area}

The study area is located in northeastern Morocco (Fig. 1). The sampling points of thermal water were scattered throughout the $18,000 \mathrm{~km}^{2}$ wide Hydraulic Basin Agency of the Moulouya River (HBAM), which discharges into the Mediterranean Sea. Based on the statistics given by HBAM for the year 2010/2011, the discharge is about $7.4 \mathrm{~m}^{3} / \mathrm{s}$ in winter and $1.8 \mathrm{~m}^{3} / \mathrm{s}$ in summer. The region is characterized by an arid climate with low precipitation and relatively high evaporation attaining $360 \mathrm{~mm} /$ year. The average temperature in the summer is about $40{ }^{\circ} \mathrm{C}$. The distribution of precipitation is spatially variable with the highest amounts of rain falling in the north. For example, the average annual rainfall in the arid Figuig region totals $120 \mathrm{~mm}$ (Jilali and Zarhloule 2015), whereas that of the Triffa plain in the north reaches $327 \mathrm{~mm}$ (Yahya et al. 2015).

The region of the study is mostly composed of Carboniferous schists (especially in the central part of the study area-see Figs. 2, 3); Triassic red clays with evaporites and basalts intercalated with dolomitic limestones; Jurassic carbonates and marls; Cretaceous sandstones, marls, and limestones; Neogene-Quaternary alluvia, gravels, sands, and conglomerates; capped by rhyolites of Neogene age. Generally, the unconfined and

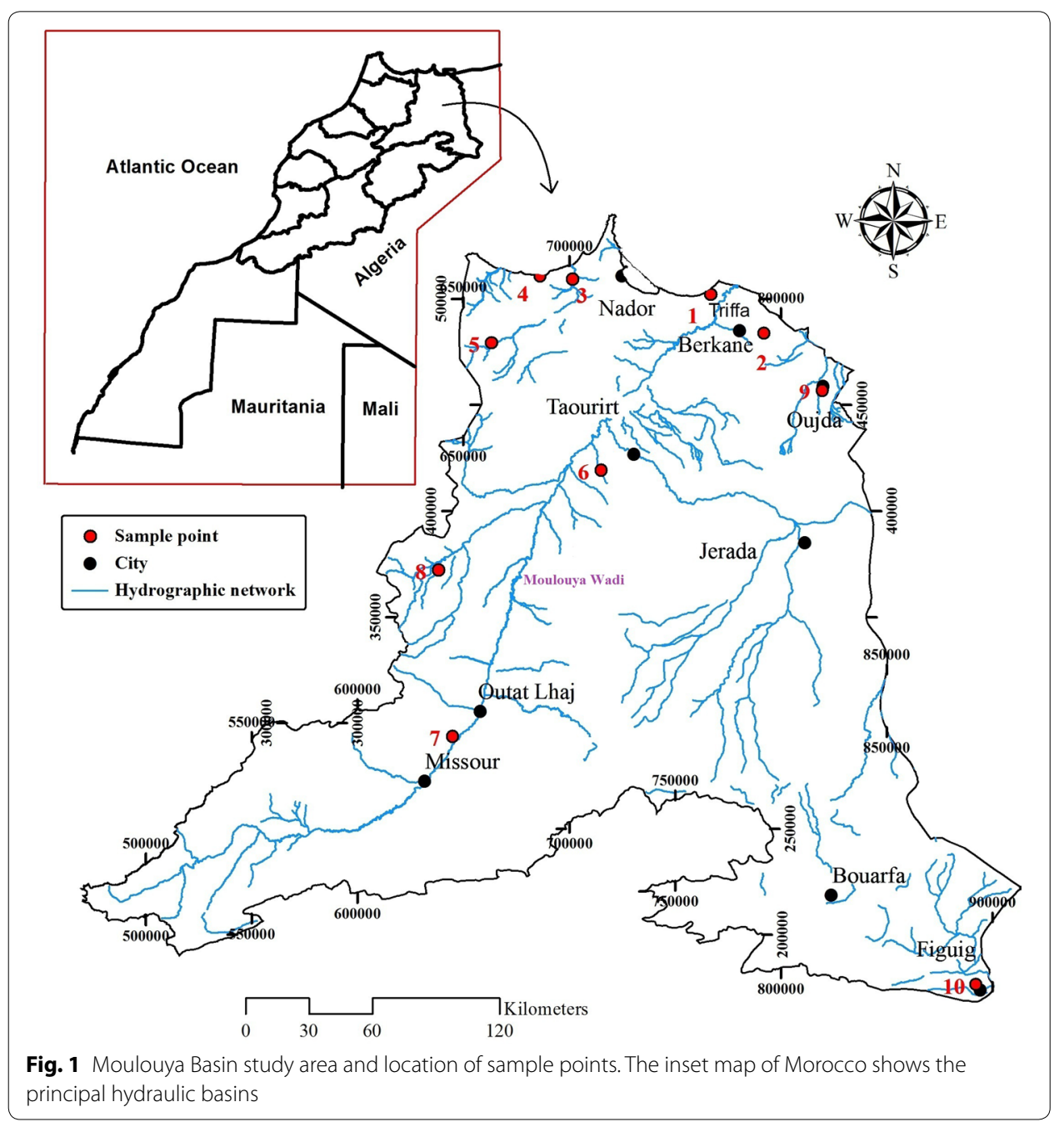




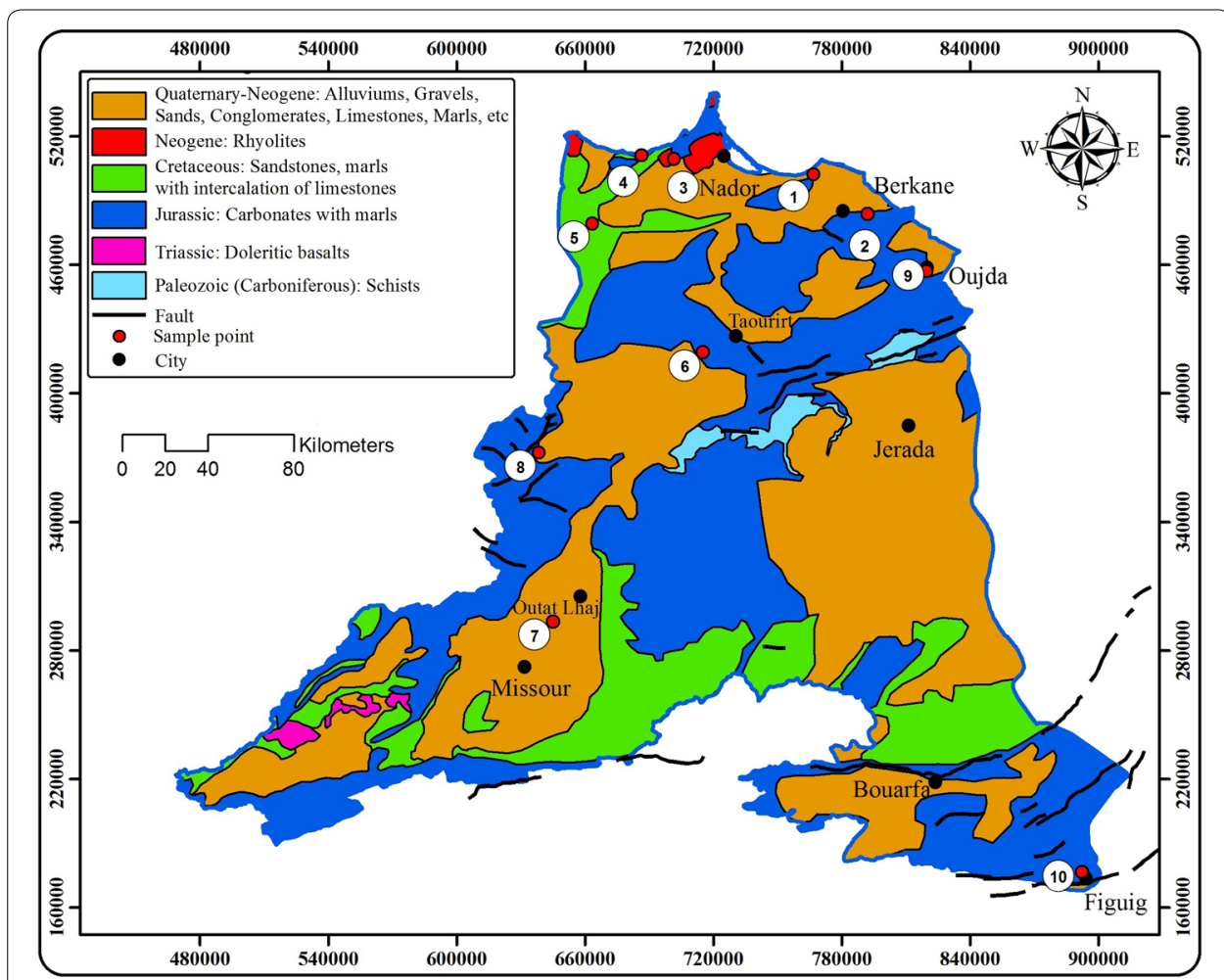

Fig. 2 Geological map of the study area

confined aquifers are formed by Cenozoic-Cretaceous and Jurassic age formations. Figure 3 shows a stratigraphic log of different aquifers hosted by the geological formations from where the samples were collected. The study area hosts numerous faults, which exhibit three main directions: ENE-WSW, NE-SW, and WNW-ESE. The structure of the study area consists of horst and grabens especially in the region of Oujda (Torbi 1988). The numerous faults play an important role in groundwater circulation, especially those in the Jurassic carbonate formations (Jilali et al. 2015b; Jilali and Zarhloule 2015).

\section{Methods}

Chemical analyses were performed on 10 groundwater samples. These were collected from deep boreholes and springs located in different parts of the study area (Fig. 1). The samples were located in the city, mountains, and on plains, such as Ben Kachour and Fezouan, Tiggour and Aïn Sidi Aïssa, respectively. An appropriate quality control procedure was carried out and the samples were handled very carefully. All the water samples were collected in polyethylene bottles (filled without leaving any air bubble) and stored in the absence of light at $4{ }^{\circ} \mathrm{C}$, with the results of chemical analyses obtained after 10 days. Field parameters of the $\mathrm{pH}$, temperature, and electrical conductivity (EC) were measured using an ORION STAR A111 and WATER PROOF CC-411. The major ions analyzed were $\mathrm{K}^{+}, \mathrm{Na}^{+}, \mathrm{Ca}^{2+}, \mathrm{Mg}^{2+}, \mathrm{Cl}^{-}, \mathrm{SO}_{4}{ }^{2-}, \mathrm{NO}_{3}{ }^{-}, \mathrm{NO}_{2}{ }^{-}, \mathrm{NH}_{4}{ }^{+}, \mathrm{H}_{2} \mathrm{PO}_{4}{ }^{-}$(SKALAR method, based on Flow Auto-Analyzer Assay Continued "FAC"), as well as $\mathrm{HCO}_{3}{ }^{-}$ (Rodier 1984) in the Labomag laboratory based in Casablanca-Morocco (http://www. 


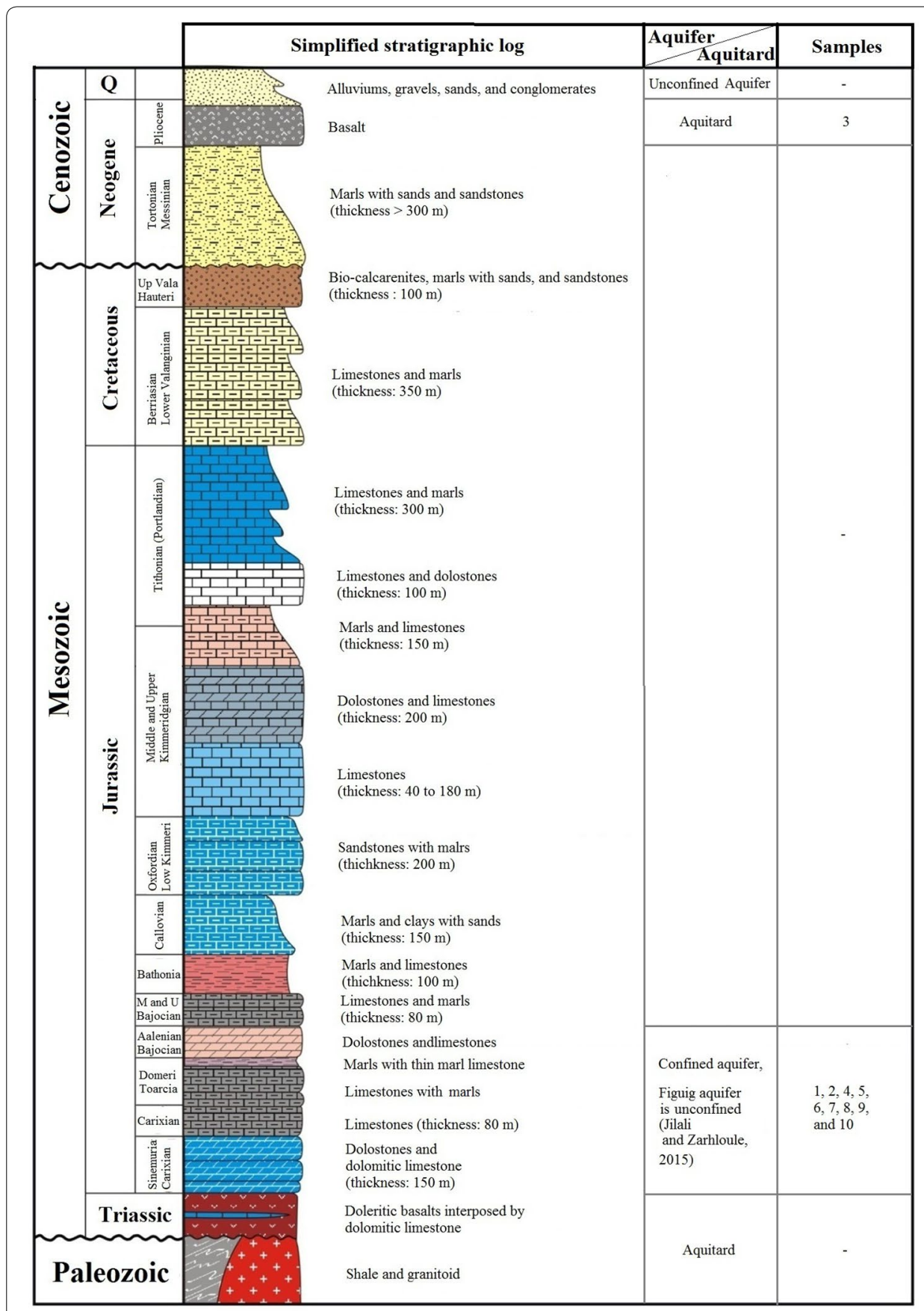

Fig. 3 Stratigraphic log of the study area [Modified from Lahrach (1999)]

labomag.ma). The precision of the chemical analyses was defined by checking the ionic charge balance. The acceptable error on the ion balance is taken at a maximum of $\pm 4 \%$.

To deduce the temperature of the geothermal reservoir, different geochemical diagrams were prepared. Data processing was performed using the AquaChem 2011.1 software (Waterloo 2011) to plot different diagrams. The reservoir temperature was estimated by applying various geothermometers: the $\mathrm{Na}-\mathrm{K}-\mathrm{Mg}$ diagram developed by 
Giggenbach et al. (1983) and $\mathrm{Na}-\mathrm{K}-\mathrm{Mg}$ geothermometers (Truesdell 1976; Fournier 1979; Michard 1979; Arnórsson 1983), whereas the geochemical modeling software PHREEQC (Parkhurst and Appelo 1999) was used to calculate the mineral saturation index $(\mathrm{SI})$.

\section{Results and discussion}

\section{Hydrochemistry}

The results of sample analyses are listed in Table 1, and include the EC, temperature ( $\mathrm{T}$ ), $\mathrm{pH}$, and the concentration of $\mathrm{K}^{+}, \mathrm{Na}^{+}, \mathrm{Ca}^{2+}, \mathrm{Mg}^{2+}, \mathrm{Cl}^{-}, \mathrm{SO}_{4}{ }^{2-}, \mathrm{NO}_{3}{ }^{-}, \mathrm{NH}_{4}{ }^{+}$, and $\mathrm{HCO}_{3}{ }^{-}$. They show that the thermal water $\mathrm{pH}$ ranges between 5.46 and 7.50. The EC ranges between 478 and 15,580 $\mu \mathrm{S} / \mathrm{cm}$, with most of the samples having very high values ( $>2000 \mu \mathrm{S} / \mathrm{cm}$ ) except for Fezouan and Hammat Moulay Yaâcoub (artesian borehole). The highest EC was recorded in samples 1, 3, and 4 near the Mediterranean Sea (coastal region) and can be justified by an intrusion of marine waters (i.e., mixing between groundwater and seawater), which is supported by the high concentration of $\mathrm{Na}^{+}$. The relatively high EC in the other samples can be explained by the hydrothermal alteration of sedimentary rocks (Fig. 3). Measurements of the $\mathrm{pH}$ indicate that the groundwater is slightly acidic to alkaline, except for the hydrothermal water of Aïn Sidi Aïssa (sample 8), which has a pH of 5.46 and a relatively high concentration of $\mathrm{HCO}_{3}{ }^{-}(1082.8 \mathrm{mg} / \mathrm{L})$. This indicates an excess dissolved $\mathrm{CO}_{2}$ in groundwater that was observed by the release of the gas bubble in the field. The temperature measurements range between 28 and $55{ }^{\circ} \mathrm{C}$ with the highest value being recorded in the Ben Kachour borehole (sample 9).

Figures 4, 5 and Table 2, identify the hydrogeochemical facies using Schöeller-Berkaloff and Piper diagrams, and the AquaChem software. The majority of hydrogeochemical facies are $\mathrm{Na}-\mathrm{Cl}$ (Samples 3, 4 and 9), $\mathrm{Na}-\mathrm{Ca}-\mathrm{Cl}$ (Samples 1, 6 and 10), $\mathrm{Ca}-\mathrm{Mg}-\mathrm{HCO}_{3}$ (Samples 2 and 7), and $\mathrm{Na}-\mathrm{Ca}-\mathrm{HCO}_{3}$ (Samples 5 and 8). Mixing of seawater with groundwater explains the changes in chemical composition of samples 1,3 , and 4 . The principal changes in groundwater composition are likely due to cation exchange processes with Liassic carbonate formations (i.e., reaction of groundwater with carbonate and the capacity of cation liberation) and an enrichment of the groundwater in $\mathrm{Ca}$ and Mg. Reverse cation exchange can be observed at the location of saline water intrusion, where the concentration of sodium increased and that of calcium decreased. For samples 6,9 , and 10, the exchange process was likely due to mixing with cold water (Barkaoui et al. 2014; Jilali et al. 2015a).

Figure 6 shows the scatter diagram of thermal water samples from the Moulouya Basin. The $\mathrm{Na}$ and $\mathrm{Cl}$ show a good correlation with $R^{2}$ equal to 0.96 , and a close correlation with the halite dissolution line for seven samples $(2,3,5,7,8,9$, and 10). These suggest a same origin for the leached soluble salts (i.e., provenance from Triassic formations). In contrast, samples 1 and 4, collected close to the coast of the Mediterranean Sea indicate mixing between seawater and groundwater, with high values of $\mathrm{Na}$. The scatter diagram of $\mathrm{Ca}+\mathrm{Mg}$ vs $\mathrm{HCO}_{3} / \mathrm{SO}_{4}$ shows a high ratio indicating a carbonate and evaporitic source for the thermal waters, i.e., an origin of $\mathrm{Ca}$ and $\mathrm{Mg}$ from Triassic formations (Belhai et al. 2016). The highest values of $\mathrm{Mg}$ (up to 46 for the most samples) indicate a near-surface reaction that leaches $\mathrm{Mg}$ from the Jurassic 


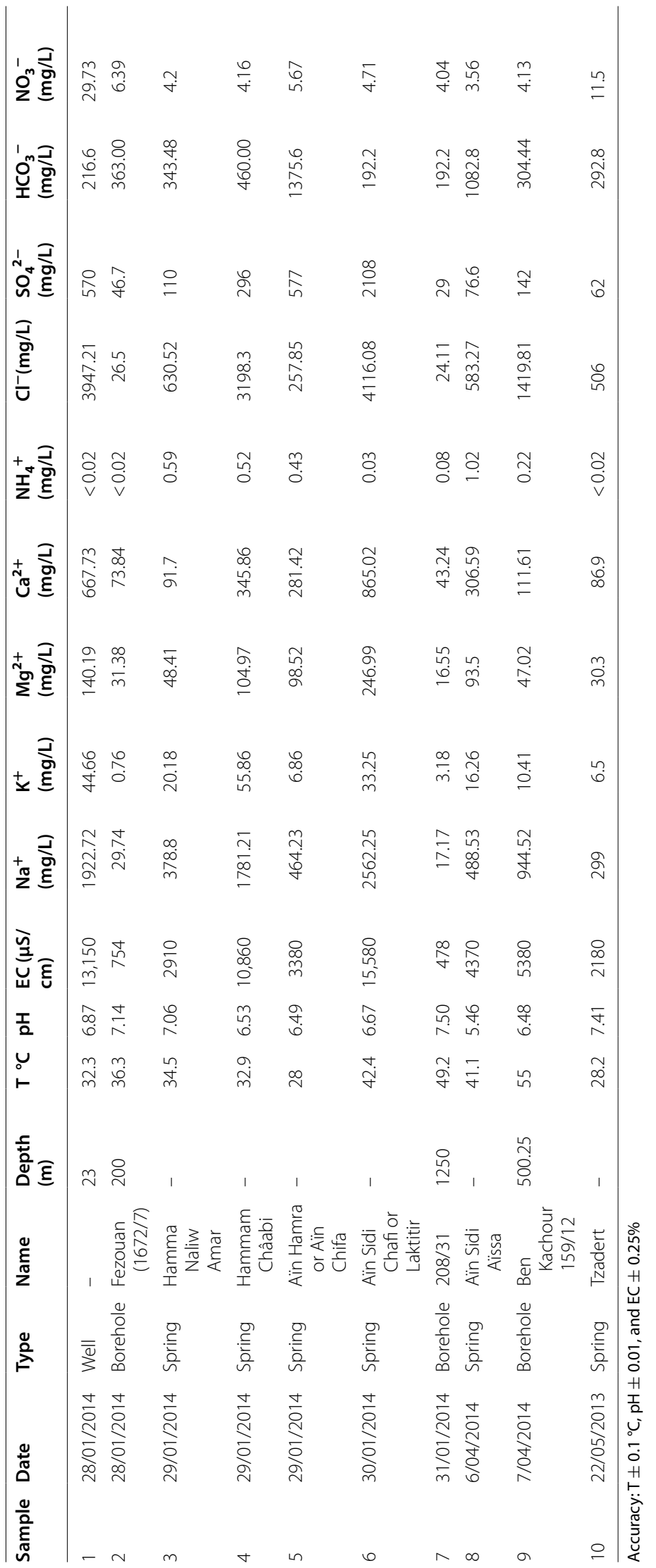



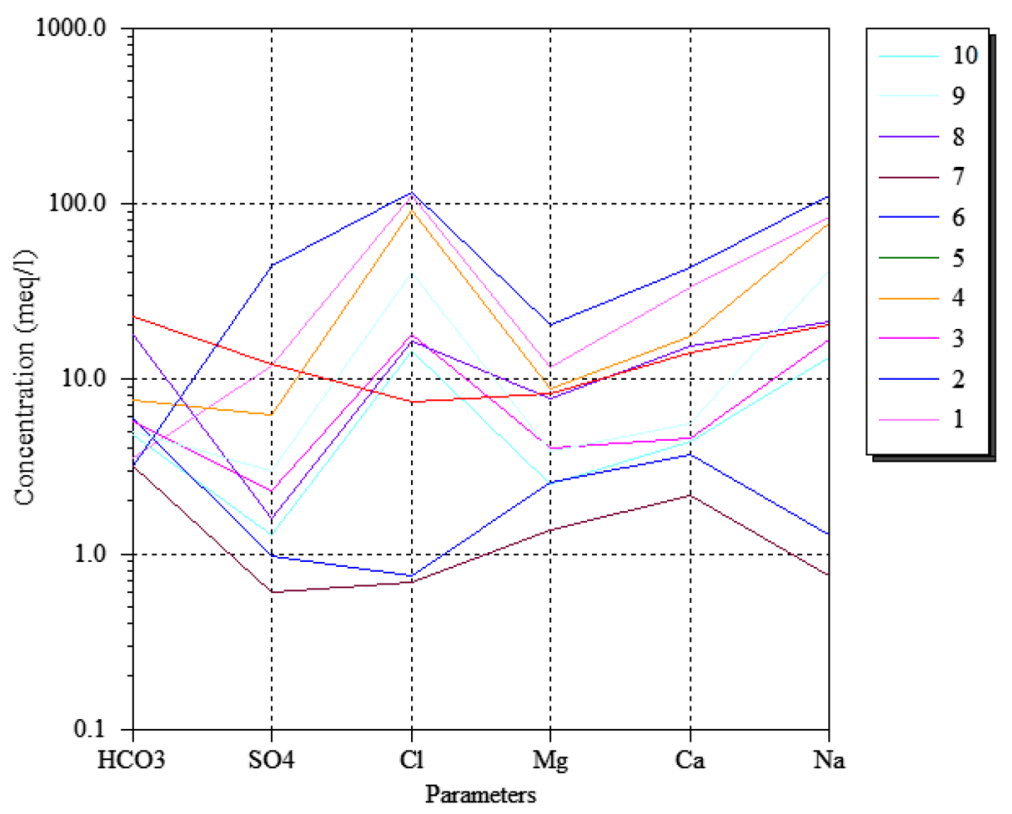

Fig. 4 Schöeller-Berkaloff diagram highlighting the hydrogeochemical facies

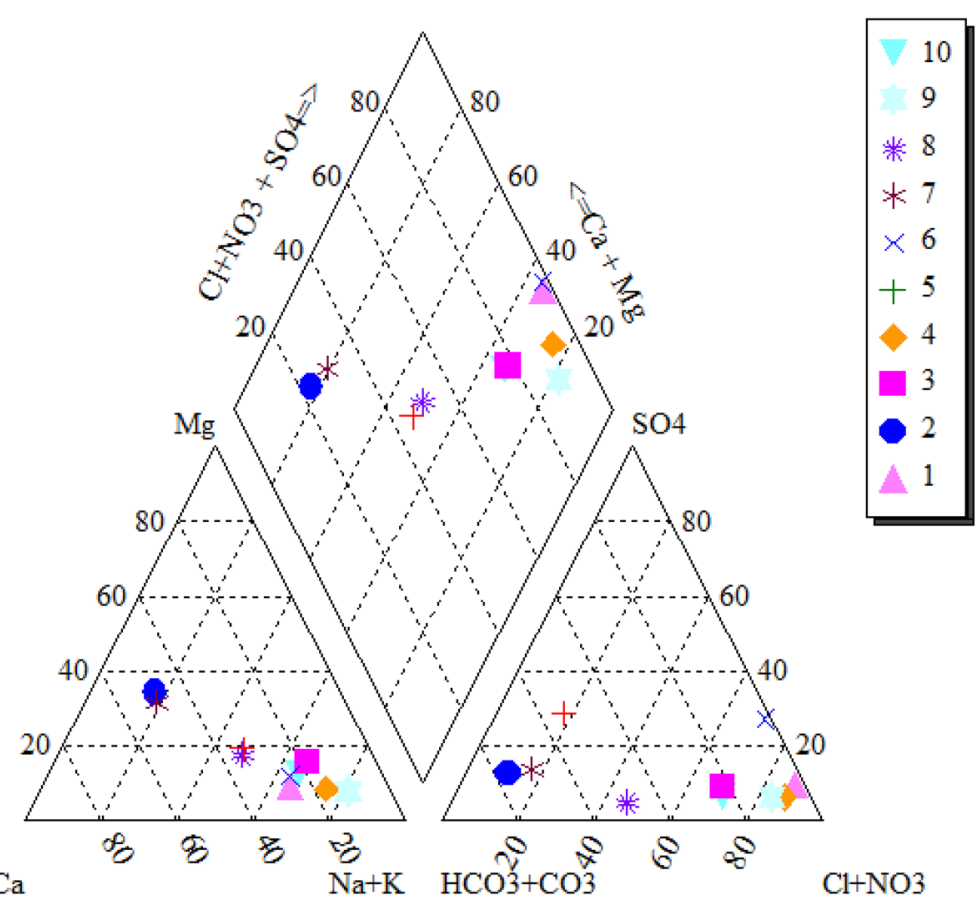

Fig. 5 Piper diagram showing the hydrogeochemical facies identified in the Moulouya Basin

carbonates (dolomite). The alteration of carbonates and silicates observed in the study area can liberate the $\mathrm{Ca}, \mathrm{Mg}$, and $\mathrm{HCO}_{3}$ from the host rocks.

The good agreement between $\mathrm{Ca}$ and $\mathrm{SO}_{4}$ concentrations with $R^{2}$ equal to 0.75 (Fig. 6), and most of the samples being close to the gypsum dissolution line indicate 
Table 2 Type of water identified in the groundwater samples

\begin{tabular}{lll}
\hline Sample & Name & Water type \\
\hline 1 & - & $\mathrm{Na}-\mathrm{Ca}-\mathrm{Cl}$ \\
2 & Fezouan (1672/7) & $\mathrm{Ca}-\mathrm{Mg}-\mathrm{HCO}_{3}$ \\
3 & Hamma Naliw Amar & $\mathrm{Na}-\mathrm{Cl}-\mathrm{HCO}_{3}$ \\
4 & Hammam Châabi & $\mathrm{Na}-\mathrm{Cl}$ \\
5 & Aïn Hamra ou Aïn Chifa (Tlat Azlaf) & $\mathrm{Na}-\mathrm{Ca}-\mathrm{HCO}_{3}-\mathrm{SO}_{4}$ \\
6 & Aïn Sidi Chafi (Laktitir, Taourirt) & $\mathrm{Na}-\mathrm{Ca}-\mathrm{Cl}_{-} \mathrm{SO}_{4}$ \\
7 & Hammat Moulay Yaâcoub, Outat Lhaj or Tiggour (208/31) $)$ & $\mathrm{Ca}-\mathrm{Mg}-\mathrm{HCO}_{3}$ \\
8 & Aïn Sidi Aïssa (Ras Lakssar) & $\mathrm{Na}-\mathrm{Ca}-\mathrm{HCO}_{3}-\mathrm{Cl}$ \\
9 & Ben Kachour (159/12) & $\mathrm{Na}-\mathrm{Cl}$ \\
10 & Tzadert (Figuig) & $\mathrm{Na}-\mathrm{Ca}-\mathrm{Cl}-\mathrm{HCO}$ \\
\hline
\end{tabular}

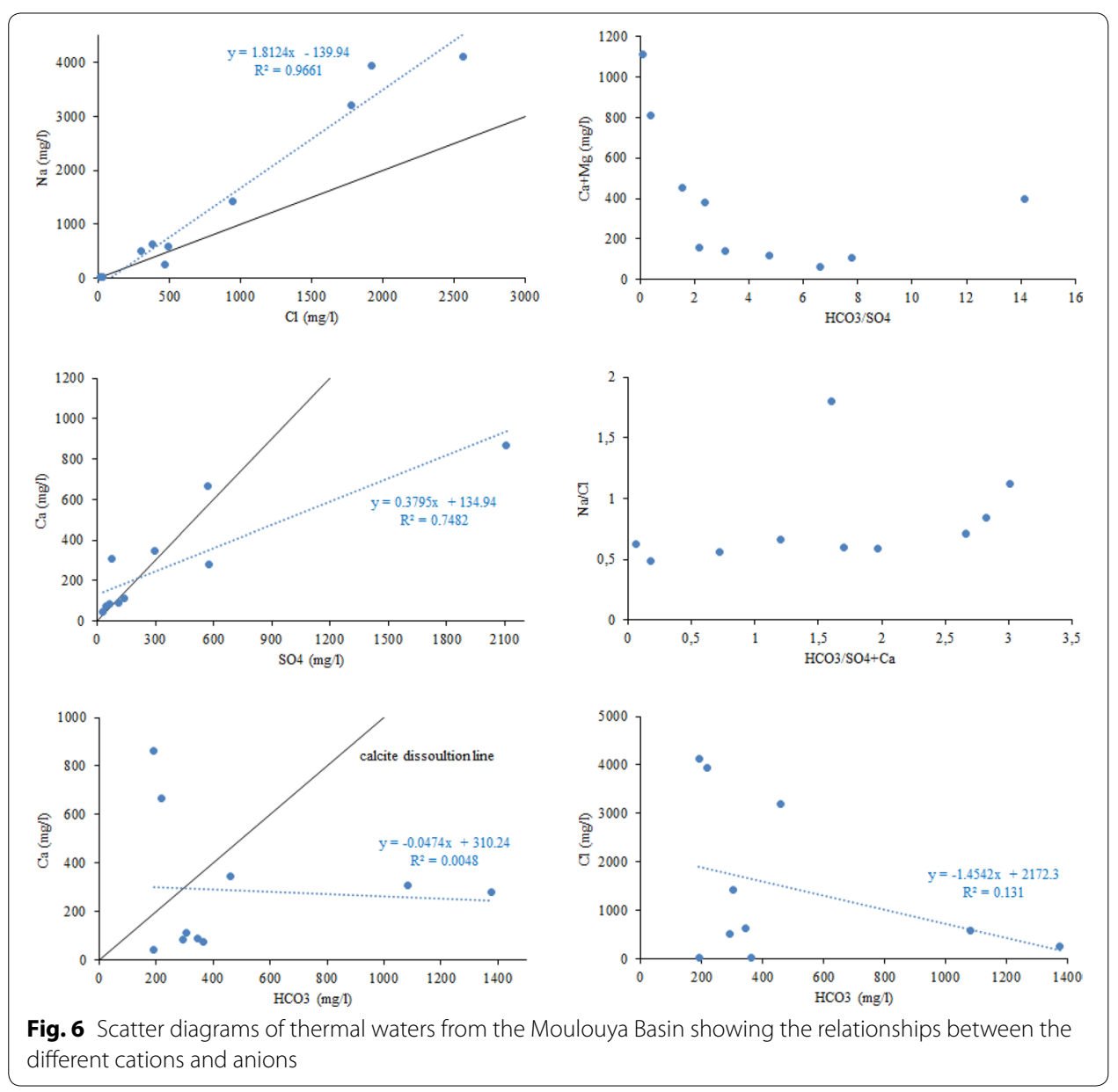

the dissolution of sulfate hosted by the Triassic rock formations (gypsum or anhydrite). The correlation between $\mathrm{Ca}$ vs $\mathrm{HCO}_{3}$ and $\mathrm{Cl}$ vs $\mathrm{HCO}_{3}$ is poor with $R^{2}$ equal to 0.005 and 0.131 , respectively, which makes any suggestion of mineralization processes questionable. The low ratio of $\mathrm{HCO}_{3} / \mathrm{Cl}$ indicates that the thermal waters flowed through a long flow path, corresponding to a deep circulation, like that described by 
Yurteri and Simsek (2017). This is confirmed by the presence of deep aquifers in the study area. In contrast, the scatter diagram of $\mathrm{Na} / \mathrm{Cl}$ vs $\mathrm{HCO}_{3} / \mathrm{SO}_{4}+\mathrm{Ca}$ confirms that the chemistry of most of the samples is largely controlled by the dissolution of halite and gypsum from the Triassic rock formations.

The diagram Cl-SO4-HCO3 (Giggenbach 1991) is similar to the Piper diagram used for the classification of natural groundwater. This diagram provides information about water origin and physico-chemical processes that it experienced. The anion-based thermal water classification indicates the presence of three types of water: chloride-, sulfate- and bicarbonate-rich (Fig. 7). Thus, samples 2, 7, and 8 (Fezouan, Hammat Moulay Yaâcoub and Aïn Sidi Aïssa) belong to the bicarbonate group and can be considered peripheral waters that mixed with cold water. The rest of the samples correspond to the chloride domain and can be considered as mature water.

\section{Geothermometry}

To estimate the geothermal reservoir temperature, different methods are used by several authors, such as chemical methods. These methods are based on the reaction between water and minerals. According to Michard (1979), at low temperature, the reaction between water and minerals reaches equilibrium slowly, and at high temperatures (reservoirs) much faster. With regard to the complexity of the water-mineral reaction, different geothermometers have been developed to estimate the reservoir temperature for the study area. Thus, several authors made estimations of the reservoir temperature, which are summarized in Table 3 (Cidu and Bahaj 2000; Zarhloule et al. 2005; Tassi et al. 2006; Barkaoui et al. 2014). In our study, three different geothermometers were used to calculate the reservoir temperature: diagram $\mathrm{Na}-\mathrm{K}-\mathrm{Mg}$ (Giggenbach, 1988), $\mathrm{Na}-\mathrm{K}-\mathrm{Mg}$

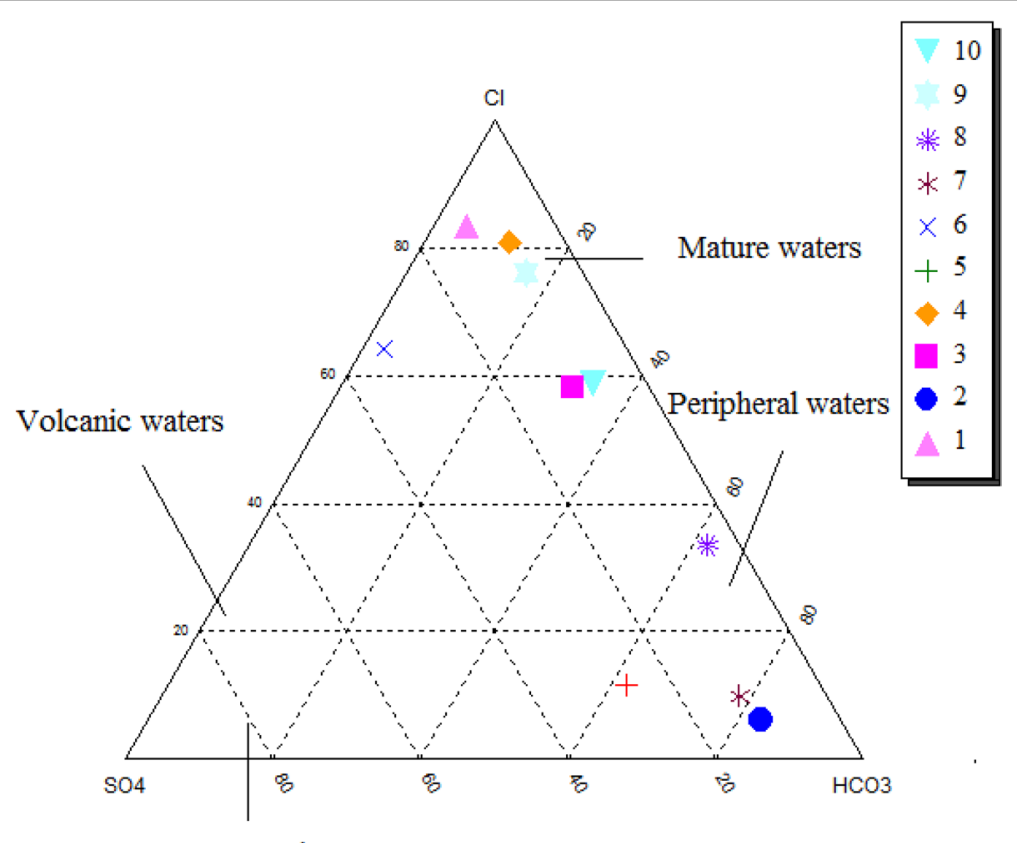

Steam Heated waters

Fig. 7 Distribution of the samples in the $\mathrm{Cl}-\mathrm{SO}_{4}-\mathrm{HCO}_{3}$ ternary diagram with mature, peripheral, volcanic, and steam head water fields highlighted 
Table 3 Temperature of the deep water reservoir in the study area, as estimated by various authors

\begin{tabular}{llllll}
\hline Sample & Name & $\begin{array}{l}\text { Cidu } \\
\text { and Bahaj } \\
(\mathbf{2 0 0 0 )}\end{array}$ & $\begin{array}{l}\text { Zarhloule } \\
\text { et al. (2005) }\end{array}$ & Tassi et al. (2006) & Barkaoui et al. (2014) \\
\hline 1 & - & - & - & - & - \\
2 & Fezouan (1672/7) & - & $40-265^{\circ} \mathrm{C}$ & - & $53-187^{\circ} \mathrm{C}$ \\
3 & Hamma Naliw Amar & - & - & $160-180^{\circ} \mathrm{C}$ & $99-170^{\circ} \mathrm{C}$ \\
4 & Hammam Châabi & - & - & - & - \\
5 & Aïn Hamra or Aïn Chifa & - & - & - & $45-129^{\circ} \mathrm{C}$ \\
6 & Aïn Sidi Chafi or Laktitir & $54-83^{\circ} \mathrm{C}$ & $54-232^{\circ} \mathrm{C}$ & $100-110^{\circ} \mathrm{C}$ & $48-106^{\circ} \mathrm{C}$ \\
7 & 208/31 & - & - & - & - \\
8 & Ain Sidi Aïssa & - & - & - & - \\
9 & Ben Kachour 159/12 & - & $60-270{ }^{\circ} \mathrm{C}$ & $100-110^{\circ} \mathrm{C}$ & $67-105^{\circ} \mathrm{C}$ \\
10 & Tzadert & - & - & & - \\
\hline
\end{tabular}

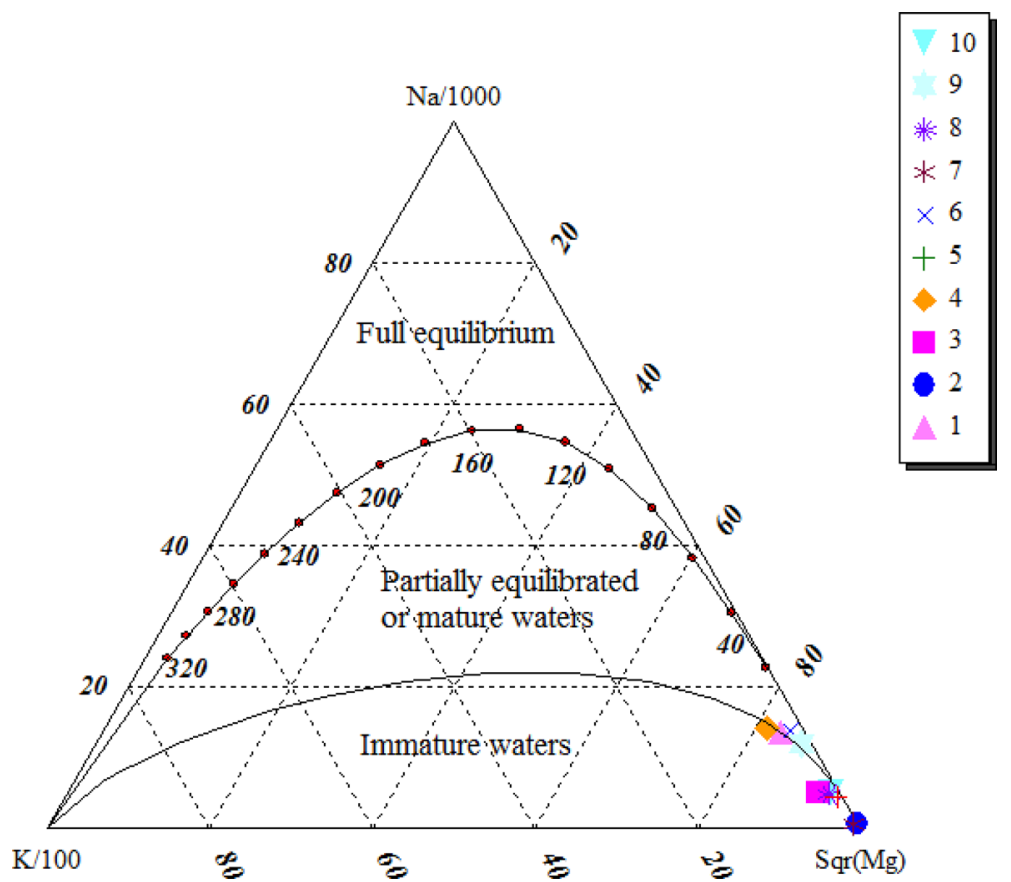

Fig. 8 Geothermal temperature reservoir of the study area using the Na-K-Mg diagram of Giggenbach (1988) highlighting the immature character of the waters from the study area

geothermometers (Truesdell 1976; Fournier 1979; Michard 1979; Tonani 1980; Arnórsson 1983; Giggenbach et al. 1983; Nieva and Nieva 1987; Giggenbach 1988), and SI method (Reed and Spycher 1984).

\section{Diagram Na-K-Mg (Giggenbach, 1988)}

The estimation of geothermal reservoir temperature using the $\mathrm{Na}-\mathrm{K}-\mathrm{Mg}$ diagram (Fig. 8) shows that the samples are situated close to the Mg pole. The samples belong to two groups: mature waters (fully equilibrated) for Aïn Sidi Chafi and Benkachour, 
and immature waters (unstable waters or incomplete equilibration, indicating mixing relationships) for the other samples, possibly also due to reactions with wall rock (Liassic dolostone). Using this diagram, the reservoir temperature obtained for the samples ranges between 80 and $170{ }^{\circ} \mathrm{C}$. These results are practically in the same range of reservoir temperature as those calculated by Tassi et al. (2006) and Barkaoui et al. (2014) for the samples: 2, 3, 5, 6, and 9, for 2 and 9 by Zarhloule et al. (2005), and for 6 by Cidu and Bahaj (2000). On the other hand, it is possible that the waters represent a mixture of cold shallow water (unconfined aquifer with anthropic activities) with thermal water. In this case, it is essential to use other models or geothermometers to calculate the reservoir temperature.

\section{$\mathrm{Na}-\mathrm{K}-\mathrm{Mg}$ geothermometers}

In this case, different geothermometer $(\mathrm{Na}-\mathrm{K}-\mathrm{Mg})$ equations are used, such as

- $\mathrm{T}^{\circ} \mathrm{C}=933 /(0.993+\log (\mathrm{Na} / \mathrm{K}))-273.15$ (Arnórsson 1983)

- $\mathrm{T}{ }^{\circ} \mathrm{C}=1319 /(1.699+\log (\mathrm{Na} / \mathrm{K}))-273.15$ (Arnórsson 1983)

- $\mathrm{T}^{\circ} \mathrm{C}=855.6 /(0.8573+\log (\mathrm{Na} / \mathrm{K}))-273.15$ (Truesdell 1976)

- $\mathrm{T}^{\circ} \mathrm{C}=908 /(0.7+\log (\mathrm{Na} / \mathrm{K}))-273.15$ (Michard 1979)

- $\mathrm{T}{ }^{\circ} \mathrm{C}=1217 /(1.483+\log (\mathrm{Na} / \mathrm{K}))-273.15$ (Fournier 1979)

- $\mathrm{T}^{\circ} \mathrm{C}=1390 /(1.52+\log (\mathrm{Na} / \mathrm{K}))-273.15$ (Giggenbach 1988)

- $\mathrm{T}^{\circ} \mathrm{C}=4410 /\left(14-\log \left(\mathrm{K}^{2} / \mathrm{Mg}\right)\right)-273.15$ (Giggenbach et al. 1983)

- $\quad \mathrm{T}^{\circ} \mathrm{C}=1178 /(1.47+(\log (\mathrm{Na} / \mathrm{K}))-273.15$ (Nieva and Nieva 1987$)$

- $\mathrm{T}{ }^{\circ} \mathrm{C}=833 /(0.78+\log (\mathrm{Na} / \mathrm{K}))-273.15$ (Tonani 1980$)$

The results obtained using nine different $\mathrm{Na}-\mathrm{K}-\mathrm{Mg}$ geothermometers are shown in Table 4. The temperature estimated varies a lot between one model and another for the same sample, and is higher than that measured in the field. Some results are incorrect (i.e., Ben Kachour and Aïn Sidi Chafi with a temperature of 43.0, 30.8, and $38.6^{\circ} \mathrm{C}$ for the geothermometers of Arnórsson (1983) and Truesdell (1976), respectively), because the temperature calculated is lower than that measured in situ. The temperature estimated for the remaining samples except Hammat Moulay Yaâcoub $\left(50-190{ }^{\circ} \mathrm{C}\right)$ is practically in the same range as the results obtained using the $\mathrm{Na}-\mathrm{K}-\mathrm{Mg}$ diagram (Fig. 8). By comparing our results with Cidu and Bahaj (2000), Zarhloule et al. (2005), and Barkaoui et al. (2014), we can conclude that the range of geothermal reservoir temperatures is different from one author to another, but the average temperature is quite similar. The most striking observation is the large interval of the estimated geothermal reservoir temperature. Because of this, another way to estimate reservoir temperature, the saturation index method (Reed and Spycher 1984), was applied to pinpoint a more narrow temperature range.

\section{Saturation index}

The Saturation Index method of estimating the reservoir temperature was developed by Reed and Spycher (1984). This method is based on the fact that the composition of water is slightly modified during the rise of water at the surface; and the SI is calculated for each temperature: $75,100,125,150,175$, and $200^{\circ} \mathrm{C}$. The results of temperature vs SI for 


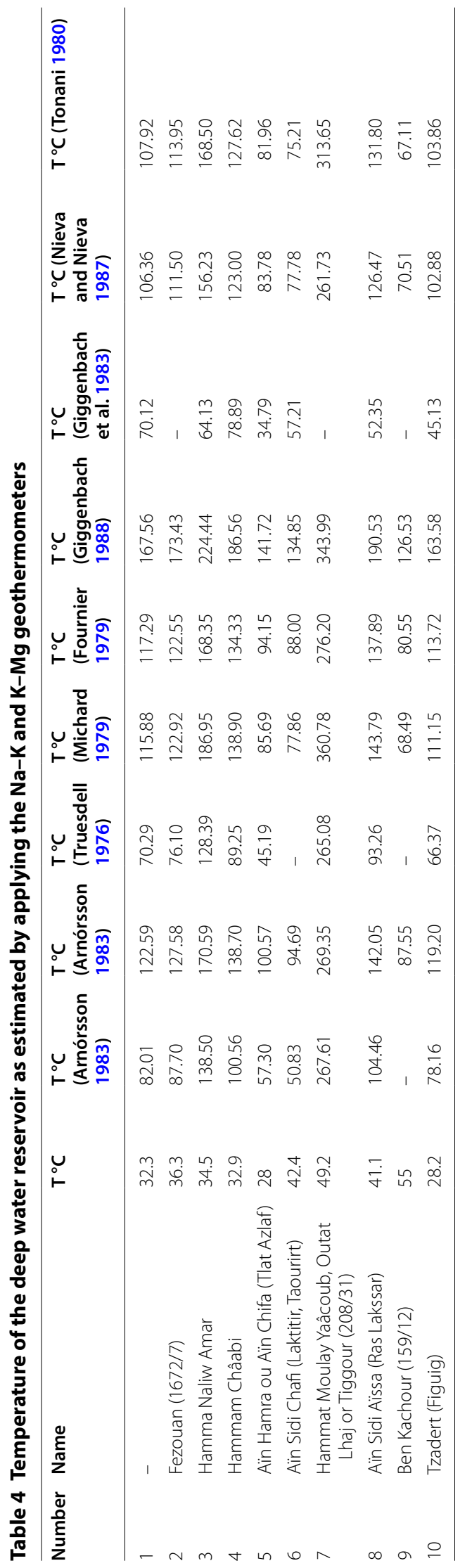




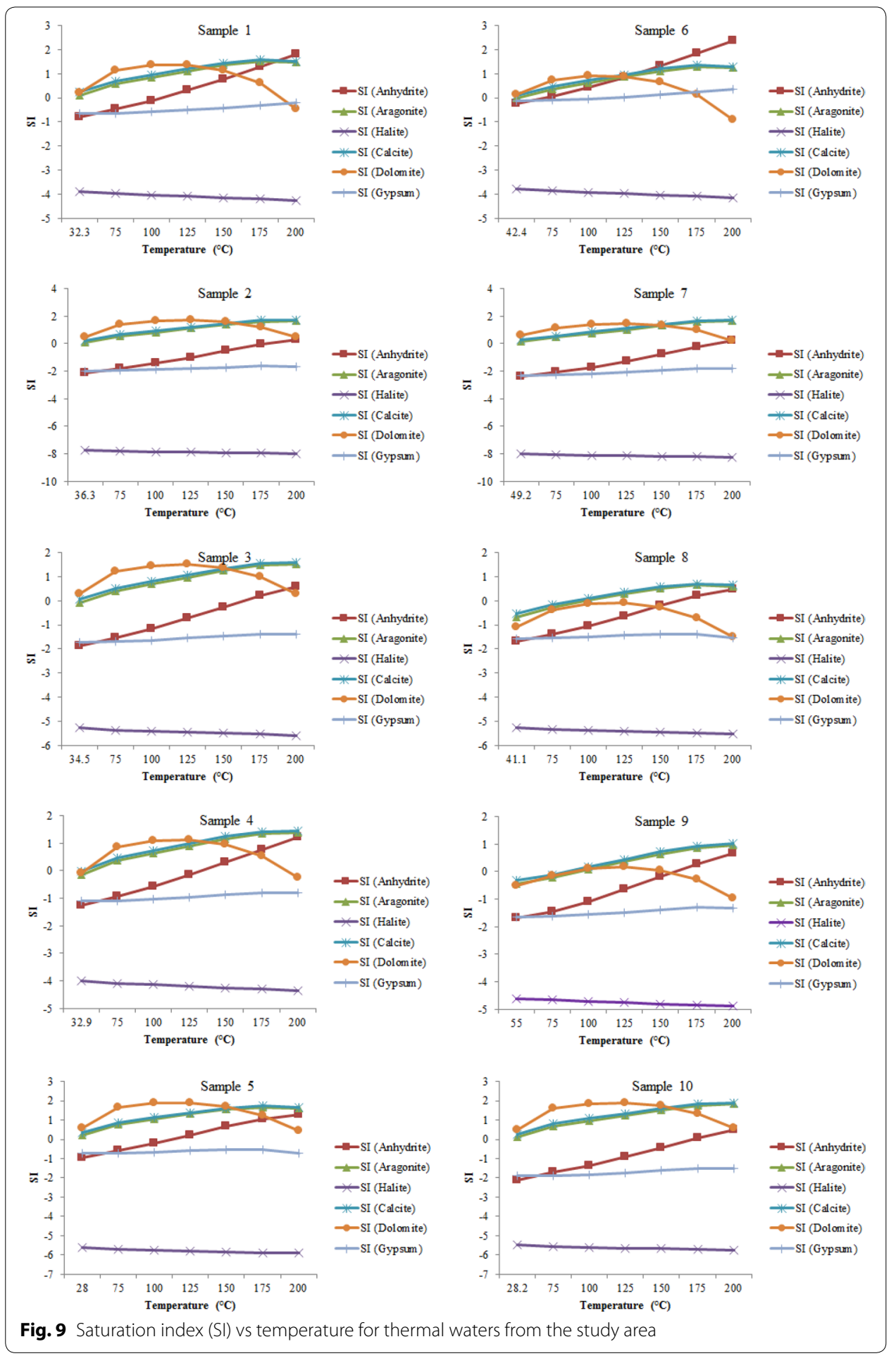

all samples are plotted in Fig. 9. The water reservoir temperature is related to the equilibrium of a maximum of minerals $(\mathrm{SI}=0)$ and is higher than that measured in situ.

Figure 9 shows that anhydrite and dolomite are close to equilibrium (SI 0) for the samples 1, Fezouan, Hamma Naliw Amar, Hammam Chaâbi, Aïn Hamra (Aïn Chifa), 
Hammat Moulay Yaâcoub, and Tzadert. The equilibrium at the above locations corresponds to the following temperature values and mineralization: $110{ }^{\circ} \mathrm{C}$ (anhydrite) $/ 190^{\circ} \mathrm{C}$ (dolomite), $175^{\circ} \mathrm{C}$ (anhydrite), $160^{\circ} \mathrm{C}$ (anhydrite) $/ 200{ }^{\circ} \mathrm{C}$ (dolomite), $135^{\circ} \mathrm{C}$ (anhydrite)/190 ${ }^{\circ} \mathrm{C}$ (dolomite), $110{ }^{\circ} \mathrm{C}$ (anhydrite)/200 ${ }^{\circ} \mathrm{C}$ (dolomite), $190{ }^{\circ} \mathrm{C}$ (anhydrite) $/ 200{ }^{\circ} \mathrm{C}$ (dolomite), and $170{ }^{\circ} \mathrm{C}$ (anhydrite), respectively. For the Aïn Sidi Chafi area, the estimated temperature is $60^{\circ} \mathrm{C}$ for anhydrite, $90-125^{\circ} \mathrm{C}$ for gypsum and $180^{\circ} \mathrm{C}$ for dolomite. Finally, Aïn Sidi Aïssa and Benkachour show the temperature of $90-100{ }^{\circ} \mathrm{C}$ and $90^{\circ} \mathrm{C}$ for the dolomite, calcite, aragonite minerals, respectively, and $160^{\circ} \mathrm{C}$ for anhydrite and dolomite. These results show the same ranges of estimated reservoir temperature as Barkaoui et al. (2014) for Aïn Chifa and Benkachour, but for the other samples (Hamma Naliw Amar, Fezouan, and Aïn Sidi Chafi'Laktitir') the temperature estimated is different, with values of $160-200^{\circ} \mathrm{C}$ and $190^{\circ} \mathrm{C}$, and less than $130{ }^{\circ} \mathrm{C}$, respectively.

\section{Conclusions}

This study investigated thermal waters in the hydraulic basin of the Moulouya River. The results show a high temperature $\left(55^{\circ} \mathrm{C}\right)$ in the Benkachour borehole. We used the hydrochemical facies identified, such as $\mathrm{Na}-\mathrm{Cl}, \mathrm{Na}-\mathrm{Ca}-\mathrm{Cl}, \mathrm{Ca}-\mathrm{Mg}-\mathrm{HCO}_{3}$, and $\mathrm{Na}-$ $\mathrm{Ca}-\mathrm{HCO}_{3}$, and various geothermometers to estimate the temperature of the geothermal reservoir. The temperature obtained ranges between 80 and $170{ }^{\circ} \mathrm{C}$, with the results obtained by the different methods being in good agreement. On the other hand, the estimated reservoir temperature for Hammat Moulay Yaâcoub (sample 7) demonstrates very high values, with an average of $295^{\circ} \mathrm{C}$ using $\mathrm{Na}-\mathrm{K}-\mathrm{Mg}$ geothermometers. Therefore, other geothermometers such as a silica geothermometer are suitable to limit the interval of estimated reservoir temperature.

\section{Authors' contributions}

$\mathrm{AJ}, \mathrm{AC}$, and $\mathrm{AE}$ carried out the fieldwork. AJ processed the data using specialized software and drafted the manuscript. $A C$ and $A E$ reviewed the literature. All authors edited the manuscript. All authors read and approved the final manuscript.

Author details

${ }^{1}$ Ministry of Energy, Mines, and Sustainable Development, Abou Marouane Essaadi Street, Rabat-Institut, BP 6208, Haut Agdal, Rabat, Morocco. ${ }^{2}$ Laboratory of Applied Geosciences, Faculty of Sciences, University Mohammed I, Boulevard Mohammed VI, 60000 Oujda, Morocco.

\section{Acknowledgements}

The authors wish to thank Dr. Mike Mlynarczyk for helping to improve this manuscript, the editor, and the anonymous reviewers.

\section{Competing interests}

The authors declare that they have no competing interests.

\section{Availability of data and materials}

All information and data necessary to understand the results and conclusions drawn in the paper are in the text, tables, and figures or can be found in cited references.

Funding

Not applicable.

\section{Publisher's Note}

Springer Nature remains neutral with regard to jurisdictional claims in published maps and institutional affiliations. 


\section{References}

Ahmad M, Akram W, Ahmad N, Tasneem MA, Rafiq M, Latif Z. Assessment of reservoir temperatures of thermal springs of the northern areas of Pakistan by chemical and isotope geothermometry. Geothermics. 2002;31(5):613-31.

Arnórsson S. Chemical equilibria in icelandic geothermal systems-Implications for chemical geothermometry in investigations. Geothermics. 1983;12:119-28.

Asta MP, Gimeno MJ, Auqué LF, Gómez J, Acero P, Lapuente P. Hydrochemistry and geothermometrical modeling of lowtemperature Panticosa geothermal system (Spain). J Volcanol Geotherm Res. 2012;235-236:84-95.

Barkaoui AE, Zarhloule Y, Rimi A, Verdoya M, Bouri S. Hydrogeochemical investigations of thermal waters in the northeastern part of Morocco. Environ Earth Sci. 2014;71(4):1767-80.

Belhai M, Fujimitsu Y, Bouchareb-Haouchine FZ, Iwanaga T, Noto M, Nishijima J. Hydrogeochemical and isotope geochemical study of northwestern Algerian thermal waters. Arab J Geosci. 2016;9(3):169.

Cidu R, Bahaj S. Geochemistry of thermal waters from Morocco. Geothermics. 2000;29(3):407-30.

Fournier R. A revised equation for Na/K geothermometer. Geotherm Res Council Trans. 1979;3:221-4

Giggenbach WF. Geothermal solute equilibria. Derivation of Na-K-Mg-Ca geoindicators. Geochim Cosmochim Acta. 1988;52:2749-65.

Giggenbach WF. Chemical techniques in geothermal exploration. In: D'Amore F, editor. Application of geochemistry in geothermal reservoir development. Rome: UNITAR/UNDP Center on Small Energy Resources; 1991. p. 119-44.

Giggenbach WF, Gonfiantini R, Jangi BL, Truesdell AH. Isotopic and chemical composition of Parbati Valley geothermal discharges, NW-Himalaya, India. Geothermics. 1983;12:199-222.

Jilali A, Fagel N, Amar M, Abbas M, Zarhloule Y. Hydrogeochemical processes constrained by multivariate statistical methods and isotopic evidence of groundwater recharge in the aquifer of Figuig, Eastern High Atlas of Morocco. Arab J Geosci. 2015a;9(1):42. https://doi.org/10.1007/s12517-015-2089-8.

Jilali A, Rimi A, Zarhloule Y, Ouzzaouit L, Barkaoui A-E, Correia A, Carneiro J. (2015). Sur la structure hydrogéothermique de la région de Figuig (Haut Atlas Oriental-Maroc). Bulletin de l'institut scientifique de Rabat. In Press.

Jilali A, Zarhloule Y. Structural control of the hydrogeology in Figuig Oasis in the eastern High Atlas of Morocco. Proc Geol Assoc. 2015;126(2):232-43.

Lahrach A. Caractérisation du réservoir liasique profond du Maroc oriental et étude hydrogéologique, modélisation et pollution de la nappe phréatique des Angads. Thèse d'Etat, Faculté des Sciences et Techniques de Fès, Maroc. 1999; p. 231.

Makni J, Ben Brahim F, Hassine S, Bouri S, Ben Dhia H. Hydrogeological and mixing process of waters in deep aquifers in arid regions: south east Tunisia. Arab J Geosci. 2014;7(2):799-809.

Michard G. Géothermomètres chimiques. Bull de BRGM III. 1979:2:183-9.

Nieva D, Nieva R. Development in geothermal energy in Mexico, part 12-A cationic composition geothermometer for prospection of geothermal resources. Heat Recovery Syst CHP. 1987;7:243-58.

Parkhurst DL, Appelo CAJ. User's guide to PHREEQC (version 2): a computer program for speciation, batch-reaction, onedimensional transport, and inverse geochemical calculations. 1999; p. 312.

Pürschel M, Gloaguen R, Stadler S. Geothermal activities in the Main Ethiopian Rift: hydrogeochemical characterization of geothermal waters and geothermometry applications (Dofan-Fantale, Gergede-Sodere, Aluto-Langano). Geothermics. 2013:47:1-12.

Reed M, Spycher N. Calculation of $\mathrm{pH}$ and mineral equilibria in hydrothermal waters with application to geothermometry and studies of boiling and dilution. Geochim Cosmochim Acta. 1984;78(7):1479-92.

Rimi A, Chalouan A, Bahi L. Heat flow in the westernmost part of the Alpine Mediterranean system (the Rif, Morocco). Tectonophysics. 1998:285(1-2):135-46.

Rimi A, Lucazeau F. Heat flow density measurements in northern Morocco. J Afr Earth Sci. 1983;6(6):835-43.

Rimi A, Zarhloule Y, Barkaoui AE, Correia A, Carneiro J, Verdoya M, Lucazeau F. Towards a de-carbonized energy system in north-eastern Morocco: prospective geothermal resource. Renew Sustain Energy Rev. 2012;16(4):2207-16.

Rodier J. L'analyse de l'eau: eaux naturelles, eaux résiduaires, eau de mer. 7th ed. Paris: Dunod; 1984.

Tassi F, Vaselli O, Moratti G, Piccardi L, Minissale A, Poreda R, Delgado Huertas A, Bendkik A, Chenakeb M, Tedesco D. Fluid geochemistry versus tectonic setting: the case study of Morocco. Geol Soc Lond Spec Publ. 2006;262(1):131-45.

Tonani F. Some remarks on the application of geochemical techniques in geothermal exploration. In: Proc. Adv. Eur. Geoth. Res., Second Symposium. 1980; Strasbourg, p. 428-443.

Torbi A. Analyse structurale et étude de la fracturation du socle hercynien et de sa couverture dans les monts du Sud Est d'Oujda, Meseta orientale, Maroc. Thèse de 3ème cycle. Université Poitiers, France, 1988. p. 186.

Trabelsi S, Makni J, Bouri S, Dhia H. Hydrochemistry of thermal waters in Northeast Tunisia: water-rock interactions and hydrologic mixing. Arab J Geosci. 2015;8(3):1743-54.

Truesdell A. Summary of section III: geochemical techniques in exploration. In: Proceedings of the 2nd U.N. symposium on the development and use of geothermal resources, vol. 1, Washington, DC: U.S. Government Printing Office; 1976; p. liii-Ixxx.

Wang J, Jin M, Jia B, Kang F. Hydrochemical characteristics and geothermometry applications of thermal groundwater in northern Jinan, Shandong, China. Geothermics. 2015;57:185-95.

Waterloo H. Aquachem 2011.1 software, Canada. 2011

Yahya HSA, Jilali A, Battioui M, Mostareh MMM, Belbachir C, Chafi A. Seasonal variation of physicochemical and bacteriological characteristics of groundwater using a GIS: Triffa plain (northeast Morocco). J Mater Environ Sci. 2015;6(9):2400-8.

Yurteri C, Simsek S. Hydrogeological and hydrochemical studies of the Kaman-Savcili-Büyükoba (Kirsehir) geothermal area, Turkey. Geothermics. 2017;65:99-112.

Zarhloule Y, Bouri S, Lahrach A, Boughriba M, Mandour AE, Dhia HB. Hydrostratigraphical study, geochemistry of thermal springs, shallow and deep geothermal exploration in Morocco: hydrogeothermal potentialities. In: Proceedings World Geothermal Congress, Antalya, Turkey, 24-29 April. 2005. 
Zarhloule Y, Lahrach A, Ben Aabidat L, Bouri S, Ben Dhia H, Khattach D. Anomalies géothermiques de surface et hydrodynamisme dans le bassin d'Agadir (Maroc). J Afr Earth Sci. 1998;27(1):71-85.

Zarhloule Y, Lahrach A, Ben Abidate L, Khattach D, Bouri S, Boukdir A, Ben Dhia H. La prospection geothermique de surface au Maroc: hydrodynamisme, anomalies thermiques et indices de surface. J Afr Earth Sci. 2001;32(4):851-67.

Zarhloule Y, Rimi A, Boughriba M, Verdoya M. La province géothermique du Maroc Nord Oriental. Revue des Energies Renouv. 2007;7:89-94.

Submit your manuscript to a SpringerOpen ${ }^{\circ}$ journal and benefit from:

- Convenient online submission

- Rigorous peer review

- Open access: articles freely available online

- High visibility within the field

- Retaining the copyright to your article

Submit your next manuscript at $\boldsymbol{\Delta}$ springeropen.com 